\title{
ANALISIS PERANCANGAN E-SCHEDULE PERKULIAHAN
}

\author{
Galih Mahalisa $^{(1)}$, Gita Ayu Syafarina ${ }^{(2)}$ \\ ${ }^{1}$ Fakultas Teknologi Informasi, UNISKA \\ Email : galih.mahalisa@gmail.com \\ ${ }^{2}$ Fakultas Teknologi Informasi, UNISKA \\ Email : gitaayusyafarina@gmail.com
}

\begin{abstract}
ABSTRAK
Sistem manajemen waktu untuk penjadwalan perkulihan pada Universitas islam kalimantan maab khususnya fakultas teknologi informasi masih kurang informatif, papan pengumunan jadwal perkuliahan mengandalkan kertas yang ditempel atau menunggu arahan dari pihak fakultas jika ada perubahan jadwal. Maka dari itu perlunya suatu sistem yang mengelola penjadwalan yang kemudian ditampilkan pada layar led masing masing kelas termasuk di fakultas, pihak dosen bisa menggunakan sistem ini sebagai cara menyampaikan alasan jika tidak hadir atau pergantian jadwal. Sistem ini dibuat dengan berbasis online sehingga bisa di akses melalui internet
\end{abstract}

Kata Kunci : Jadwal, informasi, perkuliahan, sistem, dosen

\section{PENDAHULUAN}

Sistem manajemen waktu untuk penjadwalan perkulihan pada Universitas islam kalimantan maab khususnya fakultas teknologi informasi masih kurang informatif, papan pengumunan jadwal perkuliahan mengandalkan kertas yang ditempel atau menunggu arahan dari pihak fakultas jika ada perubahan jadwal, masalah yang terjadi adalah [1] terjadi kelas kosong karena dosen yang bersangkutan terlambat datang atau terlambat memberi kabar jika tidak hadir, [2] jika terjadi perubahan jadwal perkuliahan yang mendadak, tidak semua mahasiswa bisa langsung mengetahui informasi tersebut karena kendala komunikasi, dan lain sebagainya, [3] agar tidak terjadi miskomukasi antara mahasiswa dan dosen, [4] mengontrol waktu pengajaran agar tidak terjadi manipulasi

Maka dari itu perlunya suatu sistem yang mengelola penjadwalan yang kemudian ditampilkan pada layar led masing masing kelas termasuk di fakultas, pihak dosen bisa menggunakan sistem ini sebagai cara menyampaikan alasan jika tidak hadir atau pergantian jadwal. Informasi tadi kemudian akan ditampilkan melalui led agar lebih informatif

\section{RUMUSAN MASALAH}

Berdasarkan latar belakang tersebut dapat dirumuskan masalahnya adalah membuat suatu sistem yang membuat schdule perkuliahan bisa berjalan lancar dan sistem yang lebih informatif untuk mahasiswa.

\section{TUJUAN DAN TARGET LUARAN}

1. Menganalisa perancangan sistem penjadwalan perkuliahan melalui LCD.

2. Menganalisa perancangan sistem pelaporan kehadiran dosen 
Target luaran wajib dan tambahan dalam pembuatan penelitian ini yaitu akan dipublikasikan dalam jurnal lokal yang mempunyai ISSN atau jurnal nasional terakreditasi dan sesuai bidang ilmu seperti Jurnal Techonogia

\section{METODE PENELITIAN}

Proses pengumpulan data dilakukan dengan 2 cara yaitu :

1. Pengumpulan data primer, dengan melakukan survey sesuai dengan kebutuhan data

2. Pengumpulan data sekunder, dikumpulkan dengan mengamati data dan mempelajari data tersebut.

Langkah-langkah yang ditempuh dalam menyelesaikan penelitian sebagai berikut:

1. Studi literatur

Pada tahap ini penulis mencari literatur dengan rincian sebagai berikut:

a. Mencari referensi mengenai sistem yang terkait.

b. Mencari permasalahan yang biasa ditemui pada penjadwalan.

2. Analisis sistem

Pada tahap ini dilakukan analisis masalah dari penjadwalan yang telah ada di Fakultas Teknologi Informasi dan kebutuhan sistem yang akan dibuat, termasuk batasan-batasan masalah pada sistem.

3. Perancangan dan implementasi sistem

Pada tahap ini dilakukan perancangan sesuai dengan hasil dari analisis sistem dan dilanjutkan dengan mengimplementasi hasil analisis dan perancangan ke dalam sistem.
4. Pengujian

Pada tahap ini dilakukan pengujian sistem apakah berjalan sesuai dengan tujuan penelitian.

5. Penyusunan laporan

Pada tahap ini dilakukan penulisan dokumentasi hasil analisis dan implementasi dari sistem pada penjadwalan mata kuliah dalam bentuk laporan penelitian.

\section{Implementasi sistem}

\section{a. Form login}

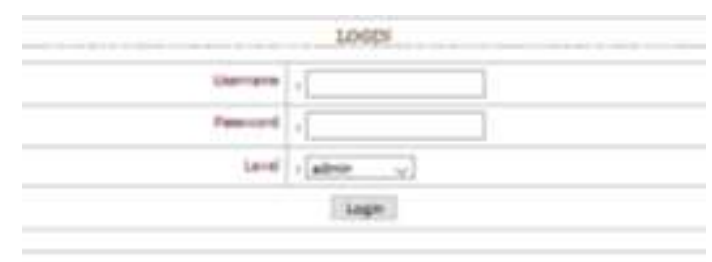

Gambar 1 Form login

b. Form jurusan

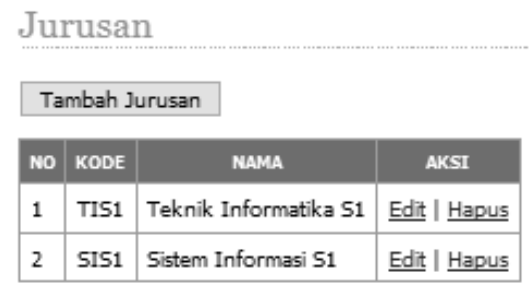

Gambar 2 jurusan

c. Form jadwal perkuliahan

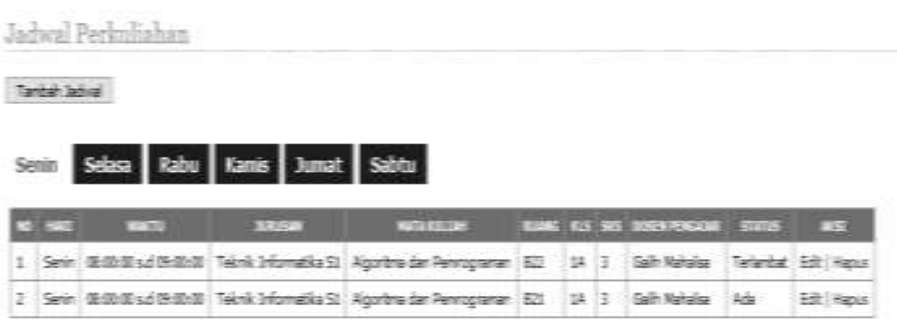

Gambar 1 jadwal perkuliahan 
d. Form e-schedule

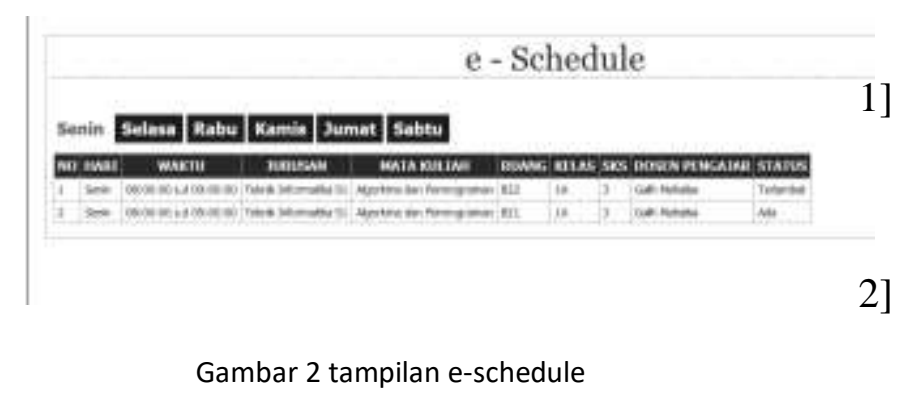

DAFTAR PUSTAKA

1] Abdul Kadir. 2010. Mudah Mempelajari Database MySQL. Yogyakarta:Andi Offset

2] Kendall, Kendall. 2010. Analisis dan Perancangan Sistem. Jakarta : Penerbit Indeks.

3] Arief, M. Rudyanto. 2011. Pemrograman Web Dinamis Menggunakan PHP dan MySQL. Yogyakarta: Andi Offset

4] Jogiyanto, HM. 2005. Analisis dan Desain Sistem Informasi: Pendekatan Terstruktur, Teori dan Praktik Aplikasi Bisnis. Yogyakarta:Andi Offset

5] Kusrini. 2007. Strategi Perancangan dan Pengelolaan Basis Data. Yogyakarta: Andi Offset adalah sebagai berikut :

1. Tampilan masih sangat sederhana jadi bisa dikembangkan menjadi lebih menarik

2. Sistem yang dibuat masih sangat sederhana yang berdasarkan ruang lingkup yang ada, perlu ditambahkan lagi pada pembuatan laporan agar tiap bulan bisa mendapatkan laporan kehadiran dosen
6] Rangga Andriyanto, 2004, Membuat Website Menggunakan Mysql, Andi Offset, Yogyakarta, 2011

7] Peranginangin, K. (2006). Aplikasi $W E B$ dengan PHP dan MySQL. Yogyakarta: ANDI. 